\title{
Response of maize and black gram yield and water productivity to variations in canopy temperature and crop water stress index**
}

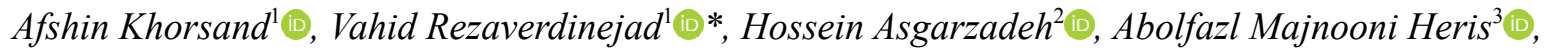 \\ Amir Rahimi ${ }^{4}$, and Sina Besharat ${ }^{1}$ (i) \\ ${ }^{1}$ Department of Water Engineering, ${ }^{2}$ Department of Soil Science, ${ }^{4}$ Department of Agronomy, \\ Urmia University, Urmia, Iran \\ ${ }^{3}$ Department of Water Engineering, University of Tabriz, Tabriz, Iran
}

Received July 15, 2020; accepted August 17, 2020

\begin{abstract}
In order to evaluate the ability of the crop water stress index to estimate grain yield and water productivity of maize and black gram in the climatic conditions of Urmia (Iran), research was conducted under the conditions of single-row drip irrigation. This study was conducted in a randomized complete block design with four irrigation levels including $50\left(\mathrm{I}_{1}\right), 75\left(\mathrm{I}_{2}\right)$, $100\left(\mathrm{I}_{3}\right)$ and $125\left(\mathrm{I}_{4}\right)$ percent of the water requirements of the plants with three replications. The mean crop water stress index values for the $I_{1}, I_{2}$ and $I_{3}$ treatments were $0.53,0.44$, and 0.28 , respectively during the growth period of maize, and $0.37,0.23$, and 0.15 for black gram, respectively. In the present study, the correlation between the crop water stress index and the grain yield and also the water productivity of maize and black gram was high. According to the results, the highest grain yield for maize and black gram was obtained at crop water stress index values of 0.28 and 0.15 , respectively. Therefore, these values are recommended for the irrigation scheduling of the plants. It should be noted that the maximum water productivity index for maize and black gram was obtained at crop water stress index values of $0.44\left(\mathrm{I}_{2}\right)$ and $0.37\left(\mathrm{I}_{1}\right)$, respectively, which are the values recommended for irrigation scheduling under restricted access to water.

Keywords: canopy temperature, crop yield, CWSI, phenolic and flavonoid compounds, water stress
\end{abstract}

\section{INTRODUCTION}

Water shortages in arid and semiarid regions threaten the food security of millions of people. Since most parts of Iran are located in the arid and semi-arid belt, crop production is not possible without irrigation. In areas where crops are irrigated, proper management and planning for

*Corresponding author e-mail: v.verdinejad@urmia.ac.ir the optimal use of water may be necessary. Iran is in dire straits with regard to water resources; therefore, it is necessary to help conserve limited water resources by optimally using, maintaining and even increasing irrigation efficiency. In a situation where irrigation water shortage prevents the development of a cultivation area, the optimum and economical use of water can increase the profit per unit area (Ahmadi et al., 2018). Water productivity actually represents the amount of product or benefit gained from water consumption and includes various aspects of water management (Ahmadi et al., 2018). The issue of irrigation management and scheduling is very important because if the irrigation scheduling methods and tools (plant and soil indices) are properly used, a significant increase in water use efficiency may be achieved (Khorsand et al., 2019).

One of the established methods of irrigation scheduling is to measure the canopy temperature, which indicates the water status of plants and is the basis of the crop water stress index (CWSI) calculation which is one of the most effective non-destructive methods (Fitzgerald et al., 2006). $C W S I$ is a valuable indicator for quantifying water stress and predicting crop yields, using CWSI for irrigation management under water stress conditions is very important (Edalat et al., 2010). CWSI is also used to estimate grain yield (GY), plant evapotranspiration and water productivity $(W P)$.

(C) 2020 Institute of Agrophysics, Polish Academy of Sciences 
In North America, two CWSI values of 0.2 and 0.4 were used for maize irrigation. Due to the use of irrigation scheduling based on a CWSI of 0.4 , the $W P$ of this crop increased from 2.3 to $2.5 \mathrm{~kg} \mathrm{~m}^{-3}$ (Stegman, 1986). Soybean irrigation scheduling with different $C W S I$ values $(0.2,0.3,0.4$ and 0.5 ) for the initiation of irrigation in a semi-arid climate was investigated and a value of 0.2 was reported as the benchmark for irrigation scheduling to achieve maximum crop yield (Nielsen, 1990). Another study in North America used $0.2,0.4$, and 0.6 water stress indices for maize, which reduced water use by 28,43 , and $54 \%$, respectively, and at a $C W S I$ value of 0.2 , crop yield does not experience a significant decrease (Steele et al., 1994).

For the irrigation scheduling of cowpea, the relationships between CWSI with evapotranspiration and crop yield were used in research. The irrigation time of the plant between 13 and 14 hours was estimated using CWSI at 0.11 (Sepaskhah and Ilampour, 1996). In another study, the efficiency of CWSI in watermelon irrigation scheduling was investigated. Five drip irrigation levels including $100,75,50,25$ and $0 \%$ soil moisture reduction were considered. Finally, the relationship between CWSI and crop performance was presented (Orta et al., 2003). The canopy temperature in different moisture conditions is affected by changes in nitrogen status, because nitrogen significantly affects the correlation between CWSI and crop yield (Meijer, 2005; Chen et al., 2010).

Researchers in Bursa (Turkey) conducted a study on soybean with five treatments of 100, 75, 50, 25 and zero percent of water requirement and a seven-day irrigation period for both 2005 and 2006 crop years and concluded that $C W S I$ may be used to determine soybean irrigation time in humid climates. They determined a CWSI limit of 0.22 . They also obtained statistical relationships between CWSI, grain yield and evapotranspiration (Candogan et al., 2013). In a study on olive trees, they set a value of 0.39 for CWSI to achieve maximum WP (Akkuzu et al., 2013). Also, the results showed that in order to achieve a maximum yield of grapes, irrigation should be implemented when CWSI is about 0.2 (Colak and Yazar, 2017).
Maize with the scientific name of Zea mays L. is a monocotyledonous, annual plant from the Geramineae and Poaceae family which has a high degree phenotypic variability. Black gram is also a plant with the scientific name Vigna mungo L. from the Fabaceae family. The black gram used in this study was grown in a vast area in the south of the West Azerbaijan province to meet the nutritional needs of the local people. The objectives of the present study are to: (i) calculate the CWSI threshold under different drip irrigation regimes, (ii) evaluate the potential of CWSI to estimate the $G Y$ and $W P$ levels of maize and black gram in the climatic conditions of Iran (Urmia city), and (iii) determine the relationship between the WP index and antioxidant compounds including phenol and flavonoid.

\section{MATERIALS AND METHODS}

This research was carried out on two maize crops (cultivar SC704) and black gram at Urmia (Iran) in the crop year 2017. The location of this field has been specified at $37^{\circ}$ 39' north latitude, $44^{\circ} 58^{\prime}$ ' east longitude and $1365 \mathrm{~m}$ a.s.l. (Khorsand et al., 2019). The climate of Iran is semi-arid. The dimensions of the plots for the two maize and black gram crops were $4 \times 3$ and $3 \times 2(\mathrm{~m} \times \mathrm{m})$, respectively, and the plots have a spacing of $2 \mathrm{~m}$. Soil samples were also taken to determine the physical properties of the soil (Table 1).

In this study, the effects of different irrigation treatments on two maize and black gram crops were investigated. The experimental design was a randomized complete block design with four water treatments of maize and black gram in three replications (Fig. 1). The water treatments were as follows: $\mathrm{I}_{1}-50 \%, \mathrm{I}_{2}-75 \%, \mathrm{I}_{3}-100 \%$ and $\mathrm{I}_{4}-$ supplying $125 \%$ of crop water requirements, respectively. Daily meteorological parameters were obtained from a meteorological station to determine water requirements (Khorsand et al., 2019). The meteorological parameters including maximum, minimum and average temperature, maximum and minimum relative humidity, hours of sunshine, wind speed and rainfall were obtained (Table 2). Then, the reference evapotranspiration $\left(E T_{\mathrm{o}}\right)$ value was calculated using the $E T_{\mathrm{o}}$ Calculator (Raes, 2009). Finally, the $E T_{\mathrm{o}}$ obtained by multiplying the crop coefficient $\left(K_{c}\right)$ (Farshi et al., 1997) was generalized for the potential evapotranspiration $\left(E T_{c}\right)$ values of maize and black gram.

Table 1. Physical properties of the experimental soil

\begin{tabular}{|c|c|c|c|c|c|c|c|c|c|c|}
\hline \multirow{3}{*}{$\begin{array}{l}\text { Soil } \\
\text { depth } \\
(\mathrm{cm})\end{array}$} & \multirow[t]{3}{*}{ Clay } & \multirow{3}{*}{$\begin{array}{r}\text { Silt } \\
(\%)\end{array}$} & \multirow[t]{3}{*}{ Sand } & \multirow{3}{*}{$\begin{array}{l}\text { Texture } \\
\text { class }\end{array}$} & \multicolumn{3}{|c|}{ Maize } & \multicolumn{3}{|c|}{ Black gram } \\
\hline & & & & & $\mathrm{FC}$ & PWP & $\mathrm{BD}$ & $\mathrm{FC}$ & PWP & BD \\
\hline & & & & & \multicolumn{2}{|c|}{$\left(\mathrm{cm}^{3} \mathrm{~cm}^{-3}\right)$} & $\left(\mathrm{g} \mathrm{cm}^{-3}\right)$ & \multicolumn{2}{|c|}{$\left(\mathrm{cm}^{3} \mathrm{~cm}^{-3}\right)$} & $\left(\mathrm{g} \mathrm{cm}^{-3}\right)$ \\
\hline $0-30$ & 44 & 50 & 6 & $\begin{array}{l}\text { Silt } \\
\text { Clay } \\
\text { Loam }\end{array}$ & 0.349 & 0.241 & 1.328 & 0.353 & 0.241 & 1.370 \\
\hline $30-60$ & 39 & 33 & 28 & $\begin{array}{l}\text { Clay } \\
\text { Loam }\end{array}$ & 0.366 & 0.279 & 1.530 & 0.360 & 0.249 & 1.473 \\
\hline
\end{tabular}

FC - field capacity, PWP - permanent wilting point, BD - bulk density. 

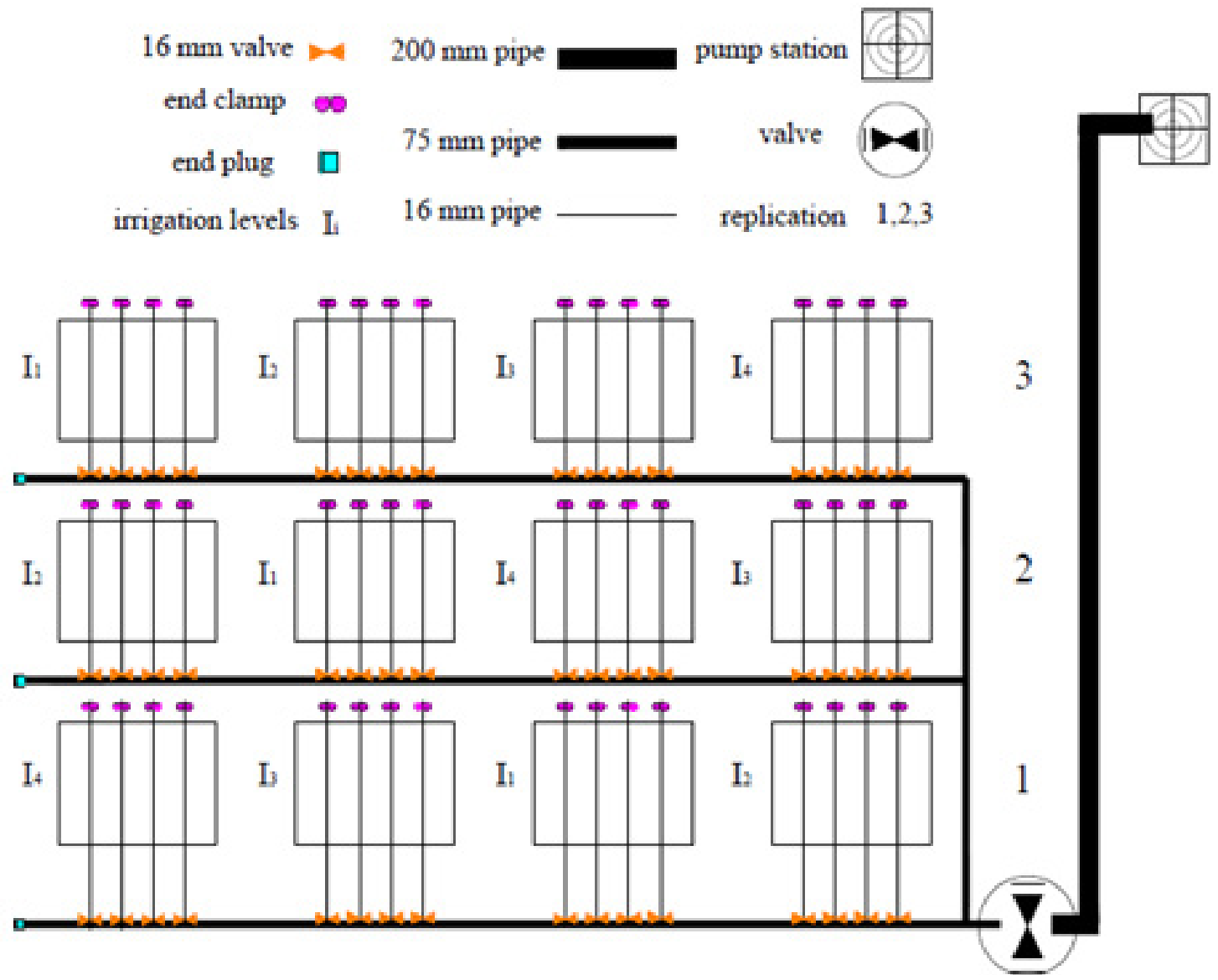

Fig. 1. Plot layout of field experiment for plants.

Table 2. Average and sum monthly weather parameters, during the 2017 growing seasons (Khorsand et al., 2019)

\begin{tabular}{|c|c|c|c|c|c|c|c|c|}
\hline \multirow{3}{*}{ Month } & \multicolumn{8}{|c|}{ Parameter } \\
\hline & \multicolumn{3}{|c|}{$\operatorname{Air}_{\text {temp }}\left({ }^{\circ} \mathrm{C}\right)$} & \multicolumn{2}{|c|}{ RH (\%) } & \multirow{2}{*}{$\begin{array}{l}\text { HBS } \\
\left(\mathrm{h} \mathrm{d}^{-1}\right)\end{array}$} & \multirow{2}{*}{$\begin{array}{c}\text { WS } \\
\left(\mathrm{m} \mathrm{s}^{-1}\right)\end{array}$} & \multirow{2}{*}{$\begin{array}{c}\mathrm{P} \\
(\mathrm{mm})\end{array}$} \\
\hline & Mean & Min & Max & Min & Max & & & \\
\hline May & 18.7 & 12.5 & 24.9 & 26 & 65 & 309.8 & 7 & 15.1 \\
\hline June & 24.0 & 16.7 & 31.3 & 24 & 54 & 341.9 & 5 & 0 \\
\hline July & 27.4 & 20.2 & 34.5 & 25 & 50 & 344.4 & 4 & 0 \\
\hline August & 26.9 & 19.6 & 34.2 & 29 & 52 & 349.0 & 3 & 2.2 \\
\hline September & 22.2 & 15.1 & 29.4 & 35 & 57 & 296.5 & 4 & 0 \\
\hline October & 14.4 & 7.9 & 21.0 & 35 & 63 & 255.4 & 5 & 3.3 \\
\hline
\end{tabular}

$\mathrm{Air}_{\text {temp }}$ - air temperature, RH - relative humidity, HBS - hours of bright sunshine, WS - wind speed, $\mathrm{P}$ - precipitation.

During the vegetation season of maize and black gram, irrigation was applied using a $16 \mathrm{~mm}$ adipose drip pipe located next to each row of crops. The $16 \mathrm{~mm}$ pipes had a constant pressure and a thickness of $1.15 \mathrm{~mm}$. In-line emitter intervals were $20 \mathrm{~cm}$ and the emitter discharge was $41 \mathrm{~h}^{-1}$. At the start of each $16 \mathrm{~mm}$ pipe, a $16 \times 16 \mathrm{~mm}$ valve was used to control the stress over time (Khorsand et al., 2019).
In the present study, a handheld infrared device was used to measure the canopy temperature $\left(T_{c}\right)$. In this study, $T_{c}$ was not measured from treatments of maize and black gram from the time of planting until 10 July due to the small size of the shrubs. Canopy temperature was measured after the complete establishment and formation of the plants and when the sky was clear and sunny in four different directions (Erdem et al., 2005) for each water treatment with 
three replications. Measurements were taken from different maize and black gram leaves at an angle of 30 to 45 degrees relative to the horizon because different plant leaves were likely to have different temperatures; therefore, the average $\mathrm{T}_{\mathrm{c}}$ was obtained by averaging these values (12 readings) (Sezen et al., 2014). Generally, $84 T_{c}$ readings were performed in $7 \mathrm{~h}$ for each treatment in one day for the maize and black gram separately.

To obtain the lower baseline equation, the $T_{c}$ values of maize and black gram were measured between the hours of $8: 50$ and $14: 50$ for $100 \%$ water requirement $\left(\mathrm{I}_{3}\right)$ on the days after irrigation (Taghvaeian et al., 2013). Also, in order to determine $C W S I$ and calculate $\left(T_{c}-T_{a}\right)_{m}$, the $T_{c}$ of maize and black gram were measured hourly from 11:50 to 14:50 in the days before irrigation for all three treatments $\left(\mathrm{I}_{1}, \mathrm{I}_{2}\right.$ and $\mathrm{I}_{3}$ ):

$\left(T_{c}-T_{a}\right)_{L . L}=a-b(A V P D)=a-b\left\{10 \times e^{\left[\frac{16.78 T_{a}-116.9}{T_{a}+237.3}\right]} \times\left(1-\frac{R H}{100}\right)\right\}$,

where: $T_{c}$ is the canopy temperature $\left({ }^{\circ} \mathrm{C}\right), T_{a}$ represents the air temperature $\left({ }^{\circ} \mathrm{C}\right), A V P D$ is the air vapour pressure deficit (mbar), $R H$ denotes the relative humidity (\%), $a$ and $b$ are the constant coefficients which are different for different products (crop and garden). The upper baseline also represents the maximum value that can be expected for $\left(T_{c}\right.$ - $T_{a}$ ) (Idso et al., 1981). CWSI is one of the indices that express the water status of the plant based on $\left(T_{c}-T_{a}\right)$ and is calculated from the following formula (Idso et al., 1981):

$C W S I=\frac{d T_{m}-d T_{L . L}}{d T_{U . L}-d T_{L . L}}=\frac{\left(T_{c}-T_{a}\right)_{m}-\left(T_{c}-T_{a}\right)_{L . L}}{\left(T_{c}-T_{a}\right)_{U . L}-\left(T_{c}-T_{a}\right)_{L . L}}$,

where: $d T_{m}$ is the difference between the canopy temperature and air temperature at the measurement time $\left({ }^{\circ} \mathrm{C}\right), d T_{L . L}$ represents the difference between the canopy temperature and air temperature obtained from the lower baseline equation for the measured $A V P D$, and $d T_{U . L}$ is a constant number for the upper baseline.

Crop harvesting was implemented at the physiological maturity stage for black gram on 09/13/2017 and maize on $03 / 10 / 2017$ by eliminating the marginal effects of each plot surface area. In order to obtain the grain yield, pods were harvested from black gram and corn from maize and samples from the harvest were transferred to the laboratory for drying. The samples were dried in an oven conditioned at $70^{\circ} \mathrm{C}$ for $48 \mathrm{~h}$, the samples were then weighed to obtain grain yield using a digital scale (0.01 precision). Finally, the plant yield numbers were generalized to one hectare.

The water productivity $(W P)$ index is one of the important indicators in the evaluation and optimal management of water consumption in irrigation projects. According to the measurement of yield and water consumption for each treatment, the WP index for different treatments of black gram and maize was calculated from the following relationship (Molden et al., 2003):

$$
W P=\frac{G Y}{V_{I}},
$$

where: $W P$ is the water productivity index $\left(\mathrm{kg} \mathrm{m}^{-3}\right), G Y$ is the grain yield $\left(\mathrm{kg} \mathrm{ha}^{-1}\right)$ and $V_{I}$ is the volume of irrigation water $\left(\mathrm{m}^{3} \mathrm{ha}^{-1}\right)$.

\section{RESULTS}

The first step for estimating CWSI is the development of lower and upper baselines for maize and black gram plants. In order to calculate the lower baseline of the experimental method of Idso et al. (1981), the $T_{c}$ of maize and black gram were measured from 8:50 a.m. to 02:50 p.m. The lower baseline equations from the results of this experimental method for the three growth stages of maize (vegetative phasefloral initiation, flowering-pollination and seed seatingseed filling) and the four growth stages of black gram (floral induction-flowering, pod formation, seed and pod filling and physiological maturity) are presented for different days after irrigation in Figs 2 and 3. The correlation between $\left(T_{c}-T_{a}\right)$ and $A V P D$ is also shown in Figs 2 and 3.

According to both sampling and field and laboratory measurements, the $G Y$ of the plants was calculated in $\mathrm{kg}$ per hectare and also through dividing the grain yield by the irrigation water, the $W P$ of maize and black gram in $\mathrm{kg} \mathrm{m}^{-3}$ was determined for each replicate of the tested treatments (Table 3). According to Table 3, crop yields decreased with the application of irrigation treatments and the stress applied to the plants and showed a greater decrease with increasing stress. The maximum average grain yield in the $\mathrm{I}_{3}$ treatment (100\% water requirement) for maize and black gram were 10.02 and $1.87 \mathrm{t} \mathrm{ha}^{-1}$, respectively and the minimum average grain yield for the $\mathrm{I}_{1}$ treatment $(50 \%$ water requirement) for maize and black gram, respectively was found to be 5.28 and $1.47 \mathrm{tha}^{-1}$, respectively.

The lower baseline equation for the experimental method Idso et al. (1981) was based on the non-stress treatment. In this study, the non-stress treatment is the $\mathrm{I}_{3}$ treatment, which is the same as the lower baseline equation for the under-stress treatments $\left(I_{1}\right.$ and $\left.I_{2}\right)$. In this experimental method, the basis of the calculations for the lower baseline equation of all treatments is the non-stress treatment. It should be noted that sometimes the measurement of canopy temperature is conducted after irrigation, this does not mean non-stress conditions exist and then the treatment data that received the most water can be used for the rest of the treatments. By examining the data and calculating the CWSI for the $\mathrm{I}_{3}$ treatment, we found that the treatment had non-stress conditions; therefore, the CWSI calculation for treatment $\mathrm{I}_{4}$ was not performed. 

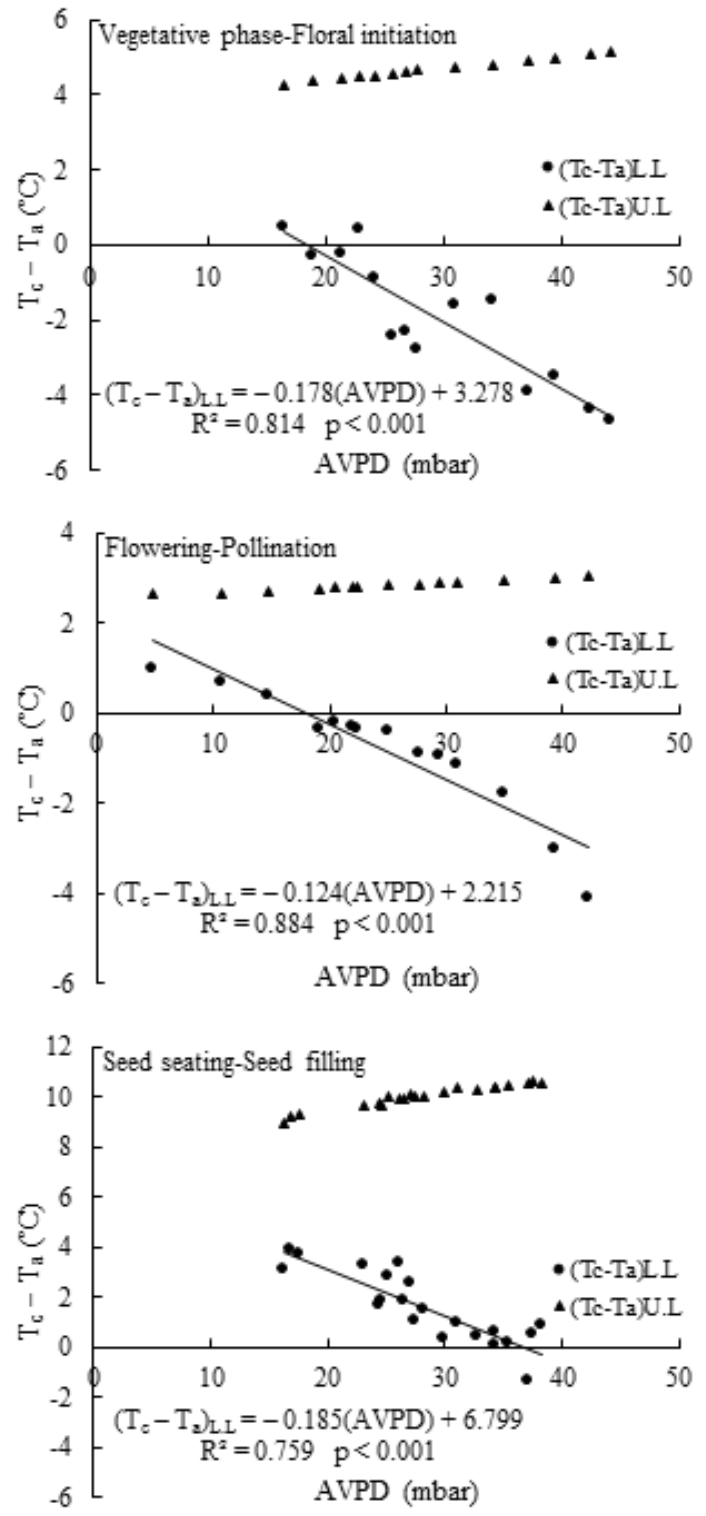

Fig. 2. Lower and upper baselines for the three stages of maize growth (Khorsand et al., 2019).

The $G Y$ relationship of maize and black gram with CWSI may be observed from the results obtained in Fig. 4. According to these figures, the relationship between $G Y$ and CWSI is inverse, that is, the lower CWSI leads to the more favourable water conditions of the plant and higher $G Y$; therefore, CWSI can be used to estimate $G Y$ under water stress conditions (Ahmadi et al., 2018). The regression relationship between the $G Y$ of maize and black gram with CWSI may be determined as follows (Fig. 4):

$$
\begin{aligned}
& G Y_{\text {maize }}=-17.53(C W S I)+15.39 \quad \mathrm{R}^{2}=0.79, \\
& G Y_{\text {black gram }}=-1.824(C W S I)+2.144 \quad \mathrm{R}^{2}=0.99,
\end{aligned}
$$

According to Fig. 4a, the maximum $G Y$ of maize for the $\mathrm{I}_{3}$ treatment ( $100 \%$ water requirement) with an average water stress index of 0.28 is equal to $10.02 \mathrm{t} \mathrm{ha}^{-1}$ and the minimum $G Y$ for the $\mathrm{I}_{1}$ treatment ( $50 \%$ water requirement) with an average water stress index of 0.53 was $5.28 \mathrm{tha}^{-1}$. Also, according to Fig. $4 \mathrm{~b}$, the maximum $G Y$ of black gram for $\mathrm{I}_{3}$ or the control treatment with an average water stress index of 0.15 is $1.88 \mathrm{tha}^{-1}$ and the minimum $G Y$ for the $\mathrm{I}_{1}$ treatment with an average water stress index of 0.37 was found to be $1.47 \mathrm{t} \mathrm{ha}^{-1}$. The higher degree of water stress in the plant causes the lower $G Y$ value of the crop.

According to the results, the highest $G Y$ values of maize and black gram were obtained at a water stress level of 0.28 and 0.15 , respectively. These values are recommended for the irrigation scheduling of maize and black gram in Iran (Urmia). Given the high degree of accuracy of the regression models obtained between the $G Y$ values of the crops and $C W S I$, one can predict the $G Y$ value of crops through these relationships by calculating $C W S I$ and the aforementioned models can also be used for better water management on the farm.

An examination of the relationship between $W P$ and the CWSI index for maize and black gram showed that there is a respectively nonlinear (uni-variate) and linear (univariate) relationship between them, as presented in Fig. 5 . According to Fig. 5, the $W P$ range for maize is between 1.5 and $1.9 \mathrm{~kg} \mathrm{~m}^{-3}$ and for black gram it is between 0.3 and $0.6 \mathrm{~kg} \mathrm{~m}^{-3}$. The highest $W P$ value in maize was related to the $\mathrm{I}_{2}$ treatment ( $75 \%$ water requirement) with a value of $1.88 \mathrm{~kg} \mathrm{~m}^{-3}$ and at a $C W S I$ value of 0.44 (Fig. 5a). Also, the highest $W P$ value in black gram was related to the $\mathrm{I}_{1}$ treatment ( $50 \%$ water requirement) with a value of $0.53 \mathrm{~kg} \mathrm{~m}^{-3}$ and at a CWSI value of 0.37 (Fig. 5b).

According to the above, the highest $W P$ value for maize and black gram were obtained respectively at a water stress index of 0.44 ( $\mathrm{I}_{2}$ treatment) and 0.37 ( $\mathrm{I}_{1}$ treatment), which are the values recommended for irrigation scheduling under access restriction conditions with high water prices. The $W P$ vs. $C W S I$ relationship for maize and black gram includes Eqs (11) and (12), respectively:

$$
\begin{gathered}
W P_{\text {maize }}=-17.17(C W S I)^{2}+14.25(C W S I)-1.067 \mathrm{R}^{2}=1.0 \\
W P_{\text {black gram }}=-0.868(C W S I)+0.207 \mathrm{R}^{2}=0.99
\end{gathered}
$$

In the present study, antioxidant activity was determined using the total phenol and flavonoid content in four water treatments $\mathrm{w}$ ith three replications for black gram and maize. According to the results obtained for black gram, the highest total phenol content $(22.6 \mathrm{mg}$ of gallic acid per $100 \mathrm{~g}$ of seed dry matter) was observed for the $\mathrm{I}_{1}$ treatment and the lowest amount (17.82 $\mathrm{mg}$ of gallic acid per $100 \mathrm{~g}$ of seed dry matter) was observed for the $\mathrm{I}_{4}$ treatment (Fig. 6a). Also, according to Fig. 6b for maize, the maximum total phenolic content $(7.68 \mathrm{mg}$ of gallic acid per $100 \mathrm{~g}$ 

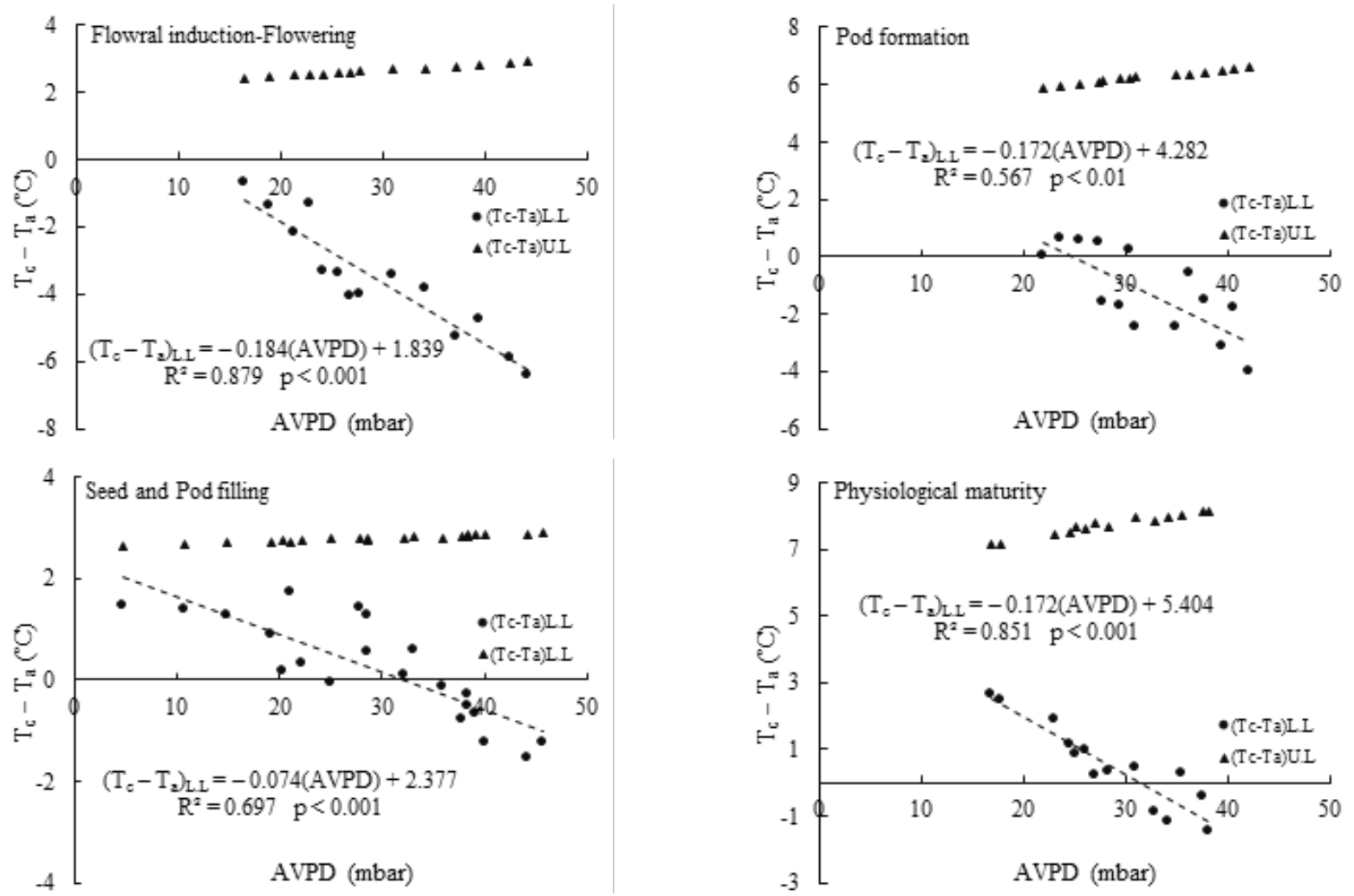

Fig. 3. Lower and upper baselines for the four stages of black gram growth.

Table 3. Quantities of irrigation volume, grain yield and water productivity of crops for different irrigation treatments

\begin{tabular}{|c|c|c|c|c|c|c|}
\hline \multirow{3}{*}{ Treatment } & \multicolumn{6}{|c|}{ Plant } \\
\hline & \multicolumn{3}{|c|}{ Maize } & \multicolumn{3}{|c|}{ Black gram } \\
\hline & $\mathrm{I}_{1}$ & $\mathrm{I}_{2}$ & $\mathrm{I}_{3}$ & $\mathrm{I}_{1}$ & $\mathrm{I}_{2}$ & $\mathrm{I}_{3}$ \\
\hline CWSI (-) & 0.53 & 0.44 & 0.28 & 0.37 & 0.23 & 0.15 \\
\hline$V_{I}\left(m^{3} h^{-1}\right)$ & 3177.80 & 4766.60 & 6355.50 & 2794.10 & 4191.20 & 5588.20 \\
\hline$G Y\left(\mathrm{~kg} \mathrm{ha}^{-1}\right)$ & 5281.11 & 8954.07 & 10021.33 & 1473.73 & 1710.33 & 1878.69 \\
\hline$W P\left(\mathrm{~kg} \mathrm{~m}^{-3}\right)$ & 1.66 & 1.88 & 1.58 & 0.53 & 0.41 & 0.34 \\
\hline
\end{tabular}

$C W S I$ - crop water stress index, $\mathrm{V}_{\mathrm{I}}$ - irrigation volume, $G Y$ - grain yield, $W P$ - water productivity.

of seed dry matter) was observed for the $\mathrm{I}_{2}$ treatment and its minimum amount $(5.47 \mathrm{mg}$ of gallic acid per $100 \mathrm{~g}$ of seed dry matter) was observed for treatment $\mathrm{I}_{4}$.

According to the results obtained for black gram, the highest flavonoid content $(15.07 \mathrm{mg}$ of quercetin per $100 \mathrm{~g}$ of seed dry matter) was observed for the $I_{1}$ treatment and the lowest amount $(8.39 \mathrm{mg}$ of quercetin per $100 \mathrm{~g}$ of seed dry matter) was associated with the $\mathrm{I}_{4}$ treatment (Fig. 7a). Also according to Fig. $7 \mathrm{~b}$ for maize, the maximum flavonoid content $(3.08 \mathrm{mg}$ of quercetin per $100 \mathrm{~g}$ of seed dry matter) was associated with the $\mathrm{I}_{2}$ treatment and its minimum value $(1.82 \mathrm{mg}$ of quercetin per $100 \mathrm{~g}$ of seed dry matter) was observed for the treatment $\mathrm{I}_{4}$.

\section{DISCUSSION}

Using the experimental method proposed by Idso et al. (1981), the values of $\left(T_{c}-T_{a}\right)$ were plotted versus $A V P D$ and, regression relationships were obtained for the growth stages of maize (three stages) and black gram (four stages) (Figs 2 and 3). In deriving regression relationships, it was assumed that the plants did not tolerate environmental stress other than water stress. According to Figs 2 and 3, the range of $A V P D$ and $\left(T_{c}-T_{a}\right)$ for the three stages of maize growth is 4 to $45 \mathrm{mbar}$ and 4 to $-5^{\circ} \mathrm{C}$, respectively, and for the four stages of black gram growth it is 4 to $46 \mathrm{mbar}$ and 3 to $-7^{\circ} \mathrm{C}$, respectively. The equations of the low base 

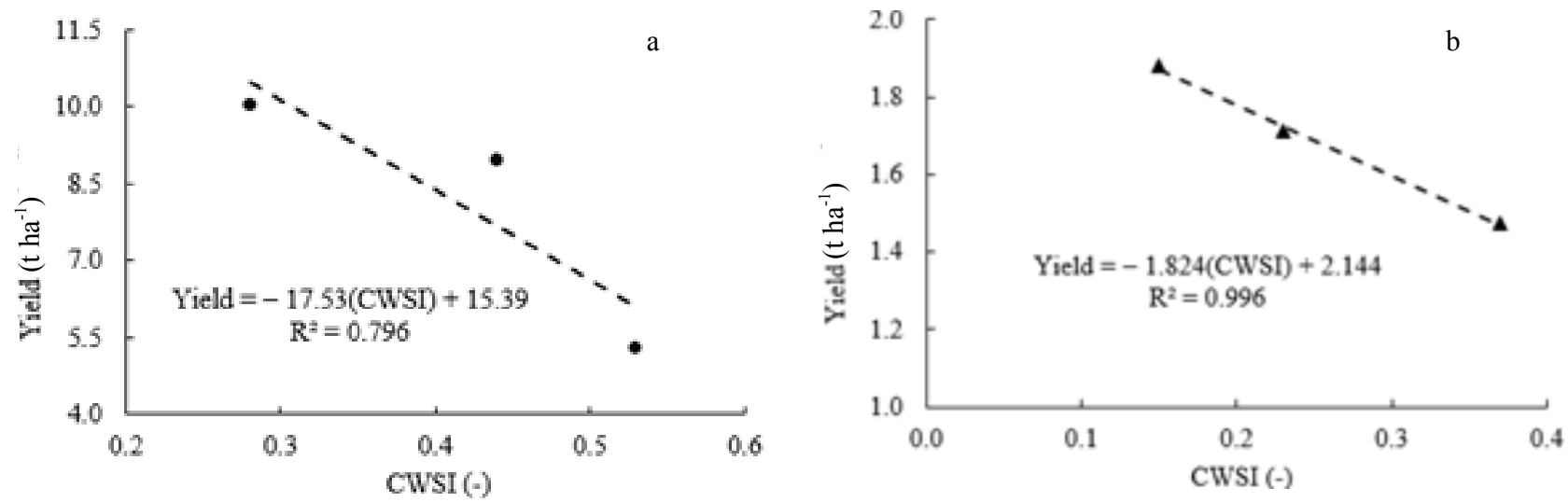

Fig. 4. Relationship between grain yield and crop water stress index of maize (a) and black gram (b).
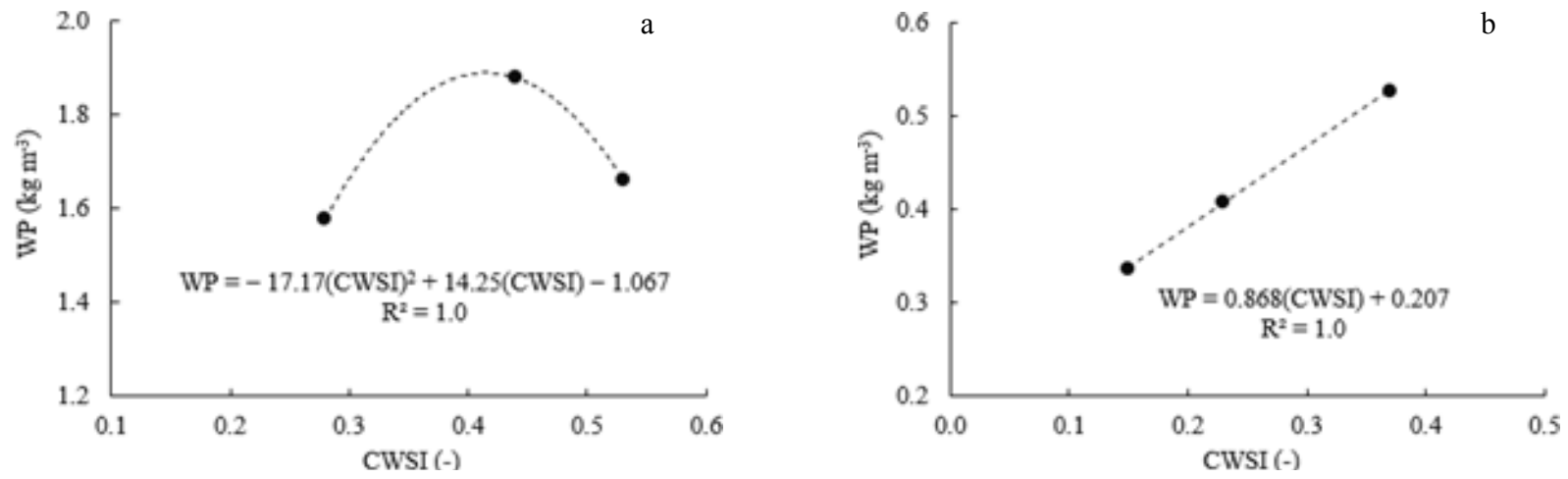

Fig. 5. Relationship between the water productivity index and crop water stress index of maize (a) and black gram (b)

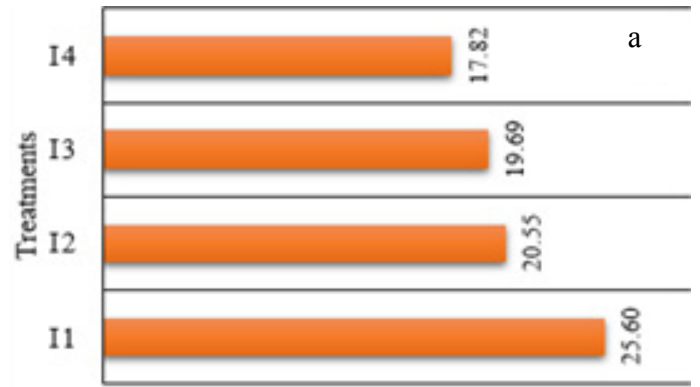

Phenolic

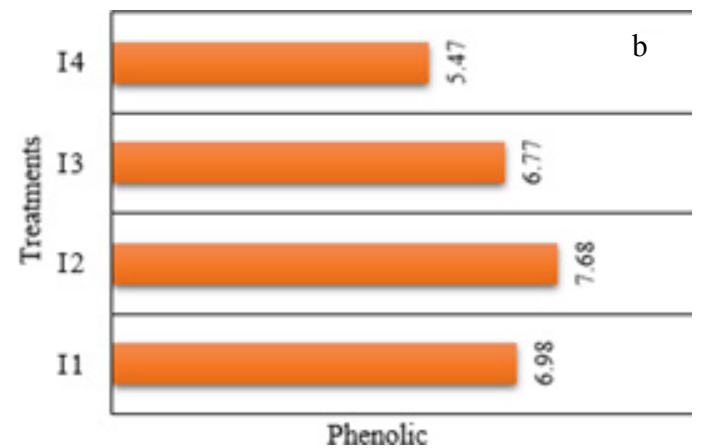

Fig. 6. Comparison of mean total phenolic content of black gram seeds (a) and maize (b) in the different irrigation treatments.
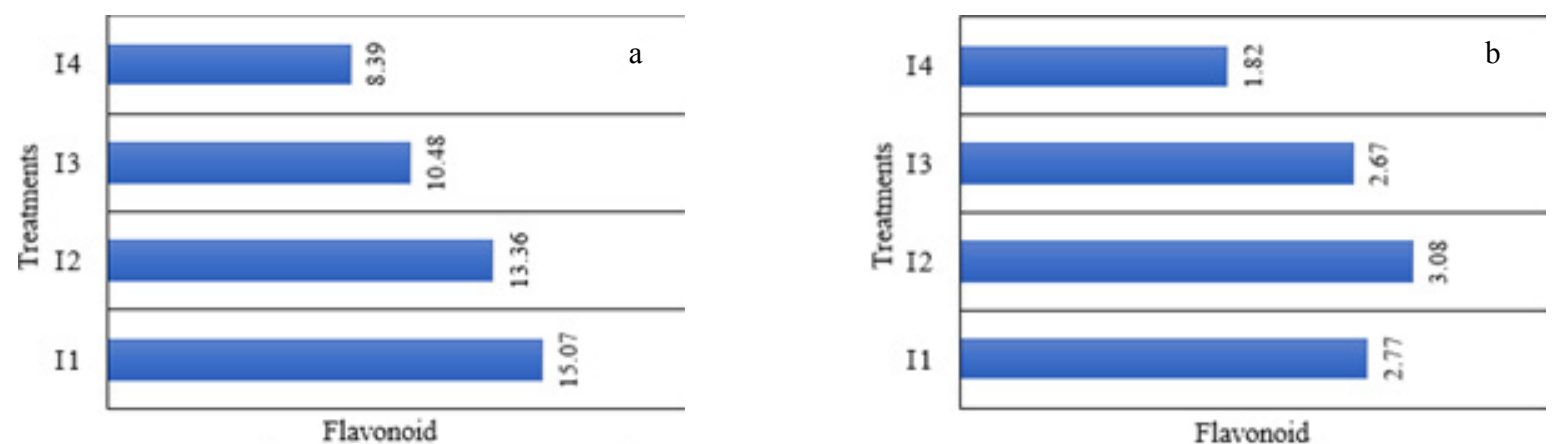

Fig. 7. Comparison of flavonoid content of black gram seeds (a) and maize (b) for the different irrigation treatments. 
lines fitted in the plant growth stages may be used in different places for maize and black gram, provided that the range of $A V P D$ is wide (Gardner and Shock, 1989). With increasing $A V P D\left(T_{c}-T_{a}\right)$ (in terms of absolute magnitude) and also evaporation and transpiration increase, moreover the $\left(T_{c}-T_{a}\right)$ increase rate decreases with time (Taghvaeian et al., 2013; Khorsand et al., 2019).

An examination of the relationships of the lower baselines showed that the values of coefficients $a$ and $b$ are different for the growth stages of the two plants. The negative slope of the line was obtained for all three stages of maize growth and the four stages of negative black gram growth (Figs 2 and 3). The reasons for the different values of coefficients $a$ and $b$ include the difference in water absorption potential as well as transpiration during the plant growth stages (Khorsand et al., 2019). Using the method of Idso et al. (1981) and according to Figs 2 and 3, the values of the upper baseline for the three stages of maize growth were found to be $4.69,2.83$ and $10.01{ }^{\circ} \mathrm{C}$ (Fig. 2), respectively, and for the four stages of growth of black gram, they were found to be $2.63,6.25,2.79$ and $7.73^{\circ} \mathrm{C}$, respectively (Fig. 3).

In the present study, the values of coefficients $a$ and $b$ of the baseline for maize were different from the results of other studies conducted for this plant (Irmak et al., 2000; Taghvaeian et al., 2012; Taghvaeian et al., 2013). The coefficients $a$ and $b$ of the first and second stages of maize plant growth are similar to those obtained by Idso (1982) and Steele et al. (1994). Also, a study by DeJonge et al. (2015) in the United States reported coefficients a and b of 2.34 and -0.179 , respectively, which were close to the coefficients of the second stage of maize growth in this study. It should also be noted that as yet no research has been conducted on the equations of the black gram base lines to compare with the results of this study. According to the studies of researchers in the field of irrigation scheduling based on CWSI, it has been determined that the location of baselines depends on the plant type and cultivar, soil type, type of irrigation system, water vapour saturation, climatic conditions and the complete cessation of transpiration in the growth stages (Taghvaeian et al., 2013; Khorsand et al., 2019). The purpose of CWSI is to provide a simple method for measuring plant water stress and to serve as a valuable tool for the irrigation scheduling of crops and garden products that can predict irrigation time (Irmak et al., 2000; Chen et al., 2010) and its value is a variable between zero and one (DeJonge et al., 2015). The mean CWSI values during the growing periods of maize and black gram for the three treatments are presented in Table 3 . The maximum CWSI of both plants is related to treatment $\mathrm{I}_{1}$ (severe deficit irrigation). The factor that increased CWSI for the $\mathrm{I}_{1}$ treatment was $T_{c}$; because the plant closed its stomas due to water stress and the $T_{c}$ of the plant increased (Taghvaeian et al., 2013).
The CWSI method has been used in various studies to manage plant irrigation. The CWSI threshold values in this study for maize and black gram undergoing the non-stress treatment were 0.28 and 0.15 , respectively, these values were the basis of irrigation scheduling. Stegman (1986) conducted a study in the United States concerning the timing of maize irrigation and used two CWSI values $(0.2$ and $0.4)$. Plant $W P$ was increased to $2.5 \mathrm{~kg} \mathrm{~m}^{-3}$ using irrigation scheduling based on CWSI (with a threshold of 0.4). In the present study, the maximum maize $W P\left(1.88 \mathrm{~kg} \mathrm{~m}^{-3}\right)$ was observed to have a CWSI value of 0.44 . It is true that the CWSI of this study is close to the CWSI obtained by Stegman (1986), but the $W P$ of maize in this study was approximately $0.62 \mathrm{~kg} \mathrm{~m}^{-3}(24.8 \%$ decrease in $W P)$ less than the WP obtained by Stegman (1986). Steele et al. (1994) conducted a similar study with maize for three years in the region where Stegman (1986) conducted a study in the United States. In this study, CWSI values of 0.2, 0.4 and 0.6 were used, which reduced water consumption by 28 , 43 and 54\%, and no significant $G Y$ reduction occurred for the product at a CWSI threshold of 0.2. Irmak et al. (2000) conducted a study on maize in Turkey and concluded that the mean CWSI should be below 0.22 to prevent a reduction in maize $G Y$. In the present study, the difference between the mean value of $C W S I$ and the result produced by Irmak et al. (2000) is 0.06 , which is about $21.4 \%$ higher, and the mean value of $C W S I$ in this research with maize should be below 0.28 so that the $G Y$ of the plant does not decrease.

In a study with different plants, the threshold value of CWSI for red pepper was 0.20 (Sezen et al., 2014), for eggplant it was 0.26 (Colak et al., 2015) and for soybean it was 0.18 (Ahmadi et al., 2018). The existence of a linear regression relationship between $G Y$ and $C W S I$ and its use to predict performance has been confirmed by other researchers (Idso et al., 1981; Orta et al., 2003; Erdem et al., 2010; Sezen et al., 2014; Çolak et al., 2015). The following regression relationships were found between $G Y\left(\mathrm{~kg} \mathrm{ha}^{-1}\right)$ and CWSI for red pepper under drip irrigation and furrow irrigation under different irrigation regimes in Turkey in 2010 and 2011 (Sezen et al., 2014):

drip irrigation:

$$
\begin{aligned}
& G Y_{2010}=-23.77 \times 10^{3}(C W S I)+48.84 \times 10^{3} \quad \mathrm{R}^{2}=0.88 \\
& G Y_{2011}=-43.52 \times 10^{3}(C W S I)+60.61 \times 10^{3} \mathrm{R}^{2}=0.90
\end{aligned}
$$

furrow irrigation:

$$
\begin{aligned}
& G Y_{2010}=-94.80 \times 10^{2}(C W S I)+38.87 \times 10^{3} \quad \mathrm{R}^{2}=0.75 \\
& G Y_{2011}=-35.07 \times 10^{3}(C W S I)+52.97 \times 10^{3} \quad \mathrm{R}^{2}=0.66
\end{aligned}
$$

In another study carried out for eggplants under different irrigation regimes using surface and subsurface drip irrigation systems in Turkey in 2013, the following regression relationships were obtained between $G Y\left(\mathrm{~kg} \mathrm{ha}^{-1}\right)$ and CWSI (Çolak et al., 2015): 
surface drip irrigation:

$G Y=-79.71 \times 10^{3}(C W S I)+94.34 \times 10^{3} \quad \mathrm{R}^{2}=0.83$,

subsurface drip irrigation:

$G Y=-78.16 \times 10^{3}(C W S I)+86.01 \times 10^{3} \quad \mathrm{R}^{2}=0.69$.

In a study conducted with soybean under different irrigation regimes using a furrow irrigation system in the climatic conditions of Khorramabad, the CWSI values for irrigation scheduling to achieve maximum $W P$ at the developmental, intermediate and final stages of plant growth were $0.42,0.37$ and 0.29 , respectively (Ahmadi et al., 2018). It should be noted that the mean CWSI in this study for black gram should be below 0.15 so that $G Y$ does not decrease. Also, no research has been done to evaluate the $C W S I$ of black gram to compare it with the results of the present study.

According to the results for phenol and flavonoid, the maximum values for black gram and maize where obtained for 50 and $75 \%$ water requirement treatments, respectively. We found that the maximum WP values for both plants were obtained for these treatments $\left(I_{1}\right.$ and $\left.I_{2}\right)$ which were discussed in the previous section; therefore, a direct relationship between phenol and flavonoid and the WP of the plants may be considered. Phenolic compounds and flavonoids are the antioxidant compounds of plants (Lindsay and Astley, 2002) which are of great physiological and morphological importance in plants (Schijlen et al., 2004). The main reason for the high antioxidant activity of some extracts is due to the high content of phenolic compounds (Jiao et al., 2005). Various factors such as genotype, climate and weather conditions, soil type, plant growth season and storage conditions affect the antioxidant activity of plants (Asekun et al., 2006). Flavonoids have the ability to cleanse active oxygen species and prevent oxidative stress. An examination of the flavonoid content of canola under drought irrigation (water stress) showed that flavonoid content increases as a secondary metabolite in the plant (Sangtarash et al., 2009). In general, the results showed that by stimulating the factors promoting the formation of phenolic compounds and flavonoids, water stress increases its content in black gram seeds, which can also be a reason for reducing transpiration in this plant. Also, given the results for black gram, it may be concluded that this plant has a high tolerance for drought and may be used as a low water plant in arid and semi-arid climates. It should be noted that promoting the cultivation of low-water medicinal plants such as lavender, garden thyme, lemon balm among others is one of the plans for the Urmia Lake Restoration project, which aims to improve farmers' livelihoods (income generation) and reduce pressure on resources and soil (reduce water use) in the Urmia Lake basin; therefore black gram can also be cultivated as one of the medicinal plants in this basin.
CONCLUSIONS

The present study was conducted in order to investigate the relationship between the crop water stress index, grain yield, water productivity and antioxidant compounds (phenol and flavonoid) of two maize (cultivar SC704) and black gram (native bulk) plants in Urmia (Iran).

1. Based on the results, the highest grain yield values for maize and black gram were obtained at a crop water stress index of 0.28 and 0.15 , respectively; therefore, these values are recommended for the irrigation scheduling of maize and black gram in Urmia (Iran). Given the high degree of accuracy of the regression models obtained between the grain yield of crops and the crop water stress index, one may predict the grain yield of the crops through the relationships between them by calculating the crop water stress index and this can also be used for better water management in the field.

2. The maximum water productivity for maize and black gram was obtained at a water stress index of $0.44\left(\mathrm{I}_{2}\right.$ treatment) and 0.37 ( $I_{1}$ treatment), respectively, which are recommended for irrigation scheduling under water restriction conditions in Urmia (Iran).

3. In general, it may be stated that the crop water stress index is capable of assessing water stress and estimating the crop produced under water stress in plants.

4. It should be noted that the direct relationship between water productivity and the antioxidant compound content of the two plants was also obtained.

Conflict of interest: The authors declare no conflict of interest.

\section{REFERENCES}

Ahmadi H., Nasrolahi A.H., Sharifipour M., and Isvand H.R., 2018. Determination of soybean water stress index (CWSI) for irrigation management for maximum yield and water productivity (in Persian). Irrigation Water Eng., 8(32), 120-131.

Akkuzu E., Kaya Ü., Çamoğlu G., Mengü G.P., and Așik Ş., 2013. Determination of crop water stress index and irrigation timing on olive trees using a handheld infrared thermometer. Irrigation Drainage Eng., 139(9), 728-737. https://doi.org/10.1061/(ASCE)IR.1943-4774.0000623.

Asekun O.T., Grieron D.S., and Afolayan A.S., 2006. Influence of drying methods on the chemical composition and yield of the essential oil of Leonotis leonurus. J. Sci. Res., 10, 61-64.

Candogan B.K., Shncik M., Buyukcangaz H., and Demirtas C., 2013. Yield, quality and crop water stress index relationships for deficit-irrigated soybean (Glycine max (L.) Merr.) in sub-humid climatic conditions. Agric. Water Manag., 118, 113-121. https://doi.org/10.1016/j.agwat.2012.11.021.

Chen J., Lin L., and Lü G., 2010. An index of soil drought intensity and degree: An application on corn and a comparison with CWSI. Agric. Water Manag., 97(6), 865-871. https:// doi.org/10.1016/j.agwat.2010.01.017. 
Çolak Y.B., Yazar A., Çolak İ., Akça H.. and Duraktekin G., 2015. Evaluation of crop water stress index (CWSI) for eggplant under varying irrigation regimes using surface and subsurface drip systems. Agriculture and Agricultural Science Procedia, 4, 372-382. https://doi.org/10.1016/j. aaspro.2015.03.042.

Çolak Y.B. and Yazar A., 2017. Evaluation of crop water stress index on Royal table grape variety under partial root drying and conventional deficit irrigation regimes in the Mediterranean Region. Scientia Horticulturae, 224, 384394. https://doi.org/10.1016/j.scienta.2017.06.032.

DeJonge K.C., Taghvaeian S., Trout T.J., and Comas L.H., 2015. Comparison of canopy temperature-based water stress indices for maize. Agric. Water Manag., 156, 51-62. https://doi.org/10.1016/j.agwat.2015.03.023.

Edalat M., Ghadiri H., and Zand-Parsa S., 2010. Corn crop water stress index under different redroot pigweed (Amaranthus retroflexus L.) densities and irrigation regimes. Archives of Agronomy Soil Sci., 56(3), 285-293. https://doi.org/10.1080/03650340903092226.

Erdem Y., Erdem T., Orta A.H., and Okursoy H., 2005. Irrigation scheduling for watermelon with crop water stress index (CWSI). Central Eur. Agric., 6(4), 449-460. https:// hrcak.srce.hr/17309.

Erdem Y., Arin L., Erdem T., Polat S., Deveci M., Okursoy H., and Gültas H., 2010. Crop water stress index for assessing irrigation scheduling of drip irrigated broccoli (Brassica oleracea L. var. italica). Agric. Water Manag., 98.1, 148156. https://doi.org/10.1016/j.agwat.2010.08.013.

Farshi A.A., Shariati M.R., Jarallahi R., Gaemi M.R., Shahabifar M., and Tavalaii M.M., 1997. Estimated Water Requirements for Major Agronomic and Horticultural Plants of the Country (in Persian). Ministry of Agriculture (TAT), Soil and Water Research Institute, Iran.

Fitzgerald G.J., Rodriguez D., Christensen L.K., Belford R., Sadras V.O., and Clarke T.R., 2006. Spectral and thermal sensing for nitrogen and water status in rain fed and irrigated wheat environments. Precision Agric., 7(4), 233-248. https://doi.org/10.1007/s11119-006-9011-z.

Gardner B.R. and Shock C.C., 1989. Interpreting the Crop Water Stress Index. ASAE, 89, 26-42.

Idso S.B., Jackson R.D., Pinter Jr P.J., Reginato R.J., and Hatfield J.L., 1981. Normalizing the stress-degree-day parameter for environmental variability. Agric. Meteorol., 24, 45-55. https://doi.org/10.1016/0002-1571(81)90032-7.

Idso S.B., 1982. Non-water-stressed baselines: A key to measuring and interpreting plant water stress. Agric. Meteorol., 27, 59-70. https://doi.org/10.1016/0002-1571(82)90020-6.

Irmak S., Haman D.Z. and Bastug R., 2000. Determination of crop water stress index for irrigation timing and yield estimation of corn. Agronomy J., 92(6), 1221-1227. https:// doi:10.2134/agronj2000.9261221x.

Jiao Z., Liu J., and Wang S., 2005. Antioxidant activities of total pigment extract from blackberries. Food Technol. Biotechnol., 43(1), 97-102. https://hrcak.srce.hr/110451.

Khorsand A., Rezaverdinejad V., Asgarzadeh H., MajnooniHeris A., Rahimi A., and Besharat S., 2019. Irrigation scheduling of maize based on plant and soil indices with surface drip irrigation subjected to different irrigation regimes. Agric. Water Manag., 224, 105740. https://doi. org/10.1016/j.agwat.2019.105740.
Lindsay D.G. and Astley S.B., 2002. European research on the functional effects of dietary antioxidants-EUROFEDA. Molecular Aspects of Medicine, 23(1-3), 1-38. https://doi. org/10.1016/s0098-2997(02)00005-5.

Meijer A.D., 2005. Characterizing a Crop Water Stress Index for Predicting Yield in Corn. A thesis submitted to the Graduate Faculty of North Carolina State University in partial fulfillment of the requirements for the Degree of Master of Science. Crop Science.

Molden D., Murray-Rust H., Sakthivadivel R., and Makin I., 2003. A water-productivity framework for understanding and action. Water productivity in agriculture: Limits and opportunities for improvement, 1-18.

Nielsen D.C., 1990. Scheduling irrigations for soybeans with the crop water stress index (CWSI). Field Crops Res., 23, 103116. https://doi.org/10.1016/0378-4290(90)90106-L.

Orta A.H., Erdem Y., and Erdem T., 2003. Crop water stress index for watermelon. Scientia Horticulturae, 98.2, 121-130.

Raes D., 2009. The $\mathrm{ET}_{0}$ Calculator Version 3.1, Reference Manual. FAO, Rome, Italy, pp. 1-38.

Sangtarash M.H., Qaderi M.M., Chinnappa C.C., and Reid D.M., 2009. Differential responses of two Stellaria longipes ecotypes to ultraviolet-B radiation and drought stress. Flora-Morphology, Distribution, Functional Ecology of Plants, 204(8), 593-603.

https://doi.org/10.1016/j.flora.2008.08.004.

Schijlen E.G., De Vos C.R., van Tunen A.J., and Bovy A.G., 2004. Modification of flavonoid biosynthesis in crop plants. Phytochemistry, 65(19), 2631-2648.

https://doi.org/10.1016/j.phytochem.2004.07.028.

Sepaskhah A.R. and Ilampour S., 1996. Relationships between yield, crop water stress index (CWSI) and transpiration of cowpea (Vigna sinensis L.). Agronomie, 16.5, 269-279.

Sezen S.M., Yazar A., Daşgan Y., Yucel S., Akyıldız A., Tekin S., and Akhoundnejad Y., 2014. Evaluation of crop water stress index (CWSI) for red pepper with drip and furrow irrigation under varying irrigation regimes. Agric. Water Manag., 143, 59-70.

https://doi.org/10.1016/j.agwat.2014.06.008

Steele D.D., Stegman E.C., and Gregor B.L., 1994. Field comparison of irrigation scheduling methods for corn. Trans. ASAE, 37(4), 1197-1203.https://doi: 10.13031/2013.28194.

Stegman E.C., 1986. Efficient irrigation timing methods for corn production. Trans. ASAE, 29(1), 203-210. https://doi: 10.13031/2013.30127.

Taghvaeian S., Cha'vez J.L., and Hansen N.C., 2012. Infrared thermometry to estimate crop water stress index and water use of irrigated maize in Northeastern Colorado. Remote Sensing, 4(11), 3619-3637. https://doi.org/10.3390/rs4113619

Taghvaeian S., Chávez J.L., Bausch W.C., DeJonge K.C., and Trout T.J., 2013. Minimizing instrumentation requirement for estimating crop water stress index and transpiration of maize. Irrigation Sci., 32(1), 53-65. https://doi.org/10.1007/ s00271-013-0415-z. 